HortSCIENCE 27(12):1314-1316. 1992.

\title{
Improved Production Procedures for Somatic Embryos of Sweetpotato for a Synthetic Seed System
}

\author{
Raymond P. Chée ${ }^{1}$ and Daniel J. Cantliffe \\ Horticultural Sciences Department, University of Florida, Institute of \\ Food and Agricultural Sciences, Gainesville, FL 32611
}

Additional index words. somatic embryogenesis, suspension culture, cell aggregates, Ipomoea batatas

\begin{abstract}
Embryogenic callus of sweetpotato [ Ipomoea batatas (L.) Lam.] disassociates in liquid medium to form a heterogeneous population of embryogenic and nonembryogenic cell aggregates of varying sizes. To improve embryo production, such cell aggregate populations were obtained by manually fragmenting calli 5 to $10 \mathrm{~mm}$ in size into liquid medium. The resulting suspensions were analyzed and the embryogenic fraction identified. The percentage of embryogenic aggregates and the percentage of aggregates forming embryos decreased with decreasing aggregate size. Thus, $76 \%$ of the 710 - to 1000 - $\mu \mathrm{m}$-diameter aggregates but only $14 \%$ of the 180 - to 250 - $\mu \mathrm{m}$ aggregates had embryogenic potential. However, only $20 \%$ of the 710- to 1000- $\mu$ m aggregates and only $2 \%$ of the 180 - to 250 - $\mu$ m aggregates actually formed embryos. Conversely, embryogenic callus and embryo production per milligram of cultured embryogenic callus increased quadratically with decreasing aggregate size. Individual torpedo-stage embryos were produced from cell aggregates 180 to $250 \mu \mathrm{m}$ in size.
\end{abstract}

Sweetpotato, a major food crop and potential biomass crop, is conventionally propagated using stem cuttings. This propagation method is costly since intensive labor and large nurseries and storage facilities are required. The lack of resistance to virus diseases further complicates the maintenance and multiplication of virus-free stocks. Mass production of disease-free plant material can be expected using tissue culture. The production of synthetic seed, through somatic embryogenesis, and direct seeding would reduce the production cost of this vegetatively propagated crop.

The application of somatic embryogenesis to synthetic seed production will require many

Received for publication 9 Aug. 1991. Accepted for publication 15 July 1992. Univ. of Florida, Agricultural Experiment Station Journal Series no. 9343. This work was supported in part by an IFAS/ Gas Research Institute cooperative grant. The cost of publishing this paper was defrayed in part by the payment of page charges. Under postal regulations, this paper thererfore must be hereby marked advertisement solely to indicate this fact. 'Sigma Cell Culture, P.O. Box 14508, St. Louis, MO 63178 embryos per amount of callus cultured in suspension and the formation of individualized embryos, Callus proliferation in sweetpotato suspension cultures occurs through cycles of growth and fragmentation (Chée and Cantliffe, 1989a). This situation is similar to that described for carrot (Daucus carota L.) suspension cultures (Halperin and Jensen, 1967; Jones, 1974; McWilliam et al., 1974). Embryogenic and nonembryogenic cell aggregates of various sizes are released when calli undergo fragmentation in suspension culture (Chée and Cantliffe, 1989a) or when calli grown on agar-solidified media are fragmented manually. In sweetpotato, embryos are produced from the released individual embryogenic cell aggregates (Chée and Cantliffe, 1989b). Embryo yields might be better optimized if the callus and embryo production potentials of cell aggregates of diverse sizes were known. Then, the appropriate suspension culture fractions could be either used to produce embryos or recycled for embryogenic callus production.

Sieving of $D$. carota callus dispersed in liquid medium and suspension cultures has been used to study the ontogeny of somatic 
Table 1. Distribution according to size of cell aggregates composing embtyogenic calli of sweetpotato and nature of growth from subcultured cell aggregates after 21 days.

\begin{tabular}{|c|c|c|c|c|c|c|c|c|c|}
\hline \multirow[b]{3}{*}{$\begin{array}{l}\text { Cell } \\
\text { aggregate } \\
\text { diam } \\
(\mu \mathrm{m}) \\
\end{array}$} & \multirow{2}{*}{\multicolumn{3}{|c|}{$\begin{array}{l}\text { Distribution of cell aggregates } \\
\text { from fragmented calli }\end{array}$}} & \multicolumn{6}{|c|}{ Growth after subculture of cell aggregates of each fraction ${ }^{y}$} \\
\hline & & & & \multicolumn{4}{|c|}{ Embryonic callus } & \multicolumn{2}{|c|}{ Nonembryonic callus } \\
\hline & $\begin{array}{c}\text { Total no. } \\
\text { aggregates } \\
(\%)\end{array}$ & $\begin{array}{l}\text { Aggregates } \\
\text { producing } \\
\text { embryogenic } \\
\text { callus } \\
(\%)\end{array}$ & $\begin{array}{c}\text { Aggregates } \\
\text { producing } \\
\text { nonembryogenic } \\
\text { callus } \\
(\%) \\
\end{array}$ & $\begin{array}{l}\text { Embryogenic } \\
\text { type } \\
\text { aggregates } \\
(\%)\end{array}$ & $\begin{array}{l}\text { Aggregates } \\
\text { producing } \\
\text { embryogenic } \\
\text { callus }^{w} \\
(\%)\end{array}$ & $\begin{array}{c}\text { Amount } \\
\text { produced/ } \\
\text { embryogenic } \\
\text { aggregates } \\
\text { (mg) }\end{array}$ & $\begin{array}{c}\text { Amount } \\
\text { produced/mg } \\
\text { embryogenic } \\
\text { aggregate } \\
\text { (mg) }\end{array}$ & $\begin{array}{c}\text { Aggregates } \\
\text { producing } \\
\text { nonembryogenic } \\
\text { callus }{ }^{\omega} \\
(\%)\end{array}$ & $\begin{array}{l}\text { Amount } \\
\text { produced/ } \\
\text { aggregate } \\
\text { (mg) }\end{array}$ \\
\hline$\overline{1000-710}$ & 1 & 6 & 1 & 55 & 76 & 9.0 & 24 & 52 & 38 \\
\hline $710-500$ & 16 & 39 & 11 & 40 & 33 & 7.2 & 50 & 38 & 33 \\
\hline $500-355$ & 13 & 20 & 6 & 26 & 21 & 6.7 & 153 & 26 & 17 \\
\hline $355-250$ & 16 & 20 & 7 & 21 & 17 & 5.9 & 358 & 24 & 13 \\
\hline $250-180$ & 15 & 15 & 5 & 11 & 14 & 5.0 & 829 & 17 & 11 \\
\hline $180-125$ & 11 & 0.1 & 20 & NA & NA & NA & NA & $\mathrm{NA}$ & NA \\
\hline $125-90$ & 28 & 0 & 50 & NA & NA & NA & NA & NA & NA \\
\hline \multirow{3}{*}{$\begin{array}{l}\text { Avg. total } \\
\text { no.w } \\
\text { F }\end{array}$} & & & & & & & & & \\
\hline & 8992 & 1223 & 4978 & NA & NA & NA & NA & NA & NA \\
\hline & NA & NA & $\mathrm{NA}$ & $\mathrm{L}^{* *}$ & $\mathrm{~L}^{* *} \mathrm{Q}^{* *}$ & $L^{* *}$ & $\mathrm{~L}^{* *} \mathrm{Q}^{* *}$ & $\mathrm{~L}^{* *}$ & NS \\
\hline
\end{tabular}

${ }^{2}$ Average of five samples of five callus lines.

yStatistical analysis was by the component of variance method; arcsin-square root transformation was used for percent analysis; $F$ test of significance was used; ${ }^{* *}$, significant at $P=0.01$; NS, nonsignificant; NA, not applicable; L, linear trend; Q, quadratic trend; 10 replicates per treatment; 50 aggregates per replicate.

xYellow aggregates of cytoplasmic cells; visually estimated at culture inception.

wAggregates without growth were not counted; some aggregates grew both embryogenic and nonembryogenic callus.

Table 2. Effect of cell aggregate size on embryo production at 21 days in sweetpotato. ${ }^{2}$

\begin{tabular}{lcccc}
\hline $\begin{array}{l}\text { Cell } \\
\text { aggregate } \\
\text { diam }\end{array}(\mu \mathrm{m})$ & $\begin{array}{c}\text { Avg aggregates/ } \\
\text { replicate } \\
(\text { no. })\end{array}$ & $\begin{array}{c}\text { Aggregates } \\
\text { with embryos } \\
(\%)\end{array}$ & $\begin{array}{c}\text { Embryos produced/ } \\
\text { aggregate } \\
\text { with embryos } \\
\text { (no.) }\end{array}$ & $\begin{array}{c}\text { Embryos produced/ } \\
\text { mg aggregate } \\
\text { with embryos } \\
\text { (no.) }\end{array}$ \\
\hline $1000-710$ & 10 & 20 & 8.8 & 23 \\
$710-500$ & 44 & 10 & 4.9 & 37 \\
$500-355$ & 52 & 4 & 3.8 & 83 \\
$355-250$ & 54 & 3 & 2.0 & 121 \\
$250-180$ & 60 & 2 & 1.3 & 223 \\
F & & $\mathrm{L}^{* *}$ & $\mathrm{~L}^{* *}$ & $\mathrm{~L}^{* *} \mathrm{Q}^{* *}$ \\
\hline
\end{tabular}

${ }^{2}$ Statistical analysis was by the component of variance method; arcsin-square root transformation was used for percent analysis. $F$ test of significance was used; ${ }^{* *}$, significant at $P=0.01 ; \mathrm{L}$, linear trend; $\mathrm{Q}$, quadratic trend; 10 replicates per treatment.

embryogenesis (Halperin, 1966; Halperin and Jensen, 1967; Halperin and Wetherell, 1964), the influence of population density (Halperin, 1964, 1967), and the effects of media constituents (Halperin and Wetherell, 1965) and to synchronize embryo development from homogeneous cell aggregate populations (Fujimura and Komamine, 1979; Halperin, 1966). In this paper we report the distribution, according to size, of cell aggregates in embryogenic callus of I. batatas and the effect of cell aggregate size on the quantitative and qualitative aspects of callus and embryo production.

Embryogenic callus of $I$. batatas 'White Star' was obtained from shoot apices and proliferated on agar-solidified medium (Chée and Cantliffe, 1988a). Eight-week-old calli 5 to $10 \mathrm{~mm}$ in diameter were collected into a layer at the bottom of a 50-ml beaker containing $10 \mathrm{ml}$ of liquid basal medium. The calli were fragmented into their natural component cell aggregates by applying slight pressure with the edge of a glass slide. The resulting suspension was fractionated using phosphor-bronze sieves with square mesh openings of 1000, 710, 500, 3.55, 250, 180, 125 , and $90 \mu \mathrm{m}$. Each fraction of cell ag gregates was resuspended separately in petri dishes containing $5 \mathrm{ml}$ of liquid basal medium. The number of embryogenic and non- embryogenic cell aggregates in each fraction were first estimated based on appearance (Chée and Cantliffe, 1989a) from five random sample visual counts at $\times 7$ to $\times 40$ magnification. Then, two l-ml aliquots of cell aggregates were plated on agar-solidified medium designed either for embryogenic callus growth or embryo formation (Chée et al., 1992). Plastic petri dishes, 60 $\times 15 \mathrm{~mm}$, with $12 \mathrm{ml}$ of medium per dish were used. Incubation was at $27 \mathrm{C}$ in darkness with unmonitored light interruptions during daily observations. The cultures were evaluated for callus or embryo production at 21 days. The whole procedure was repeated five times, starting with the collection of 8week-old calli from a new source each time. Thus, 10 samples of cell aggregates in each size range were cultured for callus growth and 10 samples for embryo production. In calculating the yields per amount of embryogenic callus cultured, we assumed that cell aggregates were spherical and that their distribution was Gaussian within each fraction. Thus, the median diameter was taken as the average diameter of aggregates within a fraction, i.e., for fraction 710 to $1000 \mathrm{pm}$, the diameter used was $855 \mu \mathrm{m}$. The density (mass per unit volume) of embryogenic cell aggregates was estimated at 1.146 by using sucrose gradients.
In suspension cultures obtained by fragmenting embryogenic callus in liquid media, $14 \%(1223 / 8992)$ of the total aggregates were embryogenic (Table 1). The 90- to $180-\mu \mathrm{m}$ fraction contained $39 \%$ of all cell aggregates, of which only $0.1 \%$ were embryogenic. The 500- to $1000-\mu \mathrm{m}$ fraction contained $17 \%$ of all cell aggregates and accounted for $45 \%$ of the total amount of embryogenic callus.

The percentage of cell aggregates producing embryogenic callus and the amount of embryogenic callus produced per cell aggregate decreased with decreasing cell aggregate size (Table 1). However, when callus production was standardized per milligram of cell aggregate, the amount of embryogenic callus produced increased with decreasing cell aggregate size. Thus, embryogenic callus production per unit mass was 35 times greater for 180 - to $250-\mu \mathrm{m}$ than for 710 - to $1000-\mu \mathrm{m}$ cell aggregates. The percentage of cell aggregates in each fraction producing nonembryogenic callus also decreased with decreasing cell aggregate size (Table 1). However, there was no statistically significant trend between the amount of nonembryogenic callus produced and cell aggregate size.

The visual classification of cell aggregates as either embryogenic (yellow, firm, small 
cytoplasmic cells) or nonemblyogenic (white, loose, vacuolated cells), made at the time the cultures were established, closely paralleled the percentage of cell aggregates that later produced embryogenic callus as expected (Table 1). The calli classifications were based on previously published work (Chée and Cantliffe, 1988a, 1989a; Liu and Cantliffe, 1984). Compact white cell aggregates with smooth surfaces were also observed. They possibly represented an embryogenic to nonembryogenic transition stage and were classified as nonembryogenic.

As cell aggregate size decreased, so did the capacity of the aggregate to produce embryos (Table 2). However, on a standardized weight value of $1 \mathrm{mg}$ of aggregate, the embryo production per milligram was 10 times greater for 180 - to $250-\mu \mathrm{m}$ cell aggregates than for 710 - to $1000-\mu \mathrm{m}$ cell aggregates. Individual embryos were produced from cell aggregates 180 to $250 \mu \mathrm{m}$ in diameter.

Sweetpotato embryogenic suspension cultures are initiated from embryogenic callus that proliferates through cycles of fragmentation into cell aggregates and growth of aggregates into new calli (Chée and Cantliffe, 1989a). The production potential of suspension cultures can be calculated from the number of embryogenic cell aggregates in each size fraction of fragmented calli (Table 1) and from the callus and embryo yields of the subcultured fractions (Tables 1 and 2). The shares of potential embryogenic callus and embryo production were, respectively, $50 \%$ and $64 \%$ for the 500 - to $1000 \mu \mathrm{m}$ fraction and, respectively, $50 \%$ and $36 \%$ for the 180 - to $500-\mu \mathrm{m}$ fraction.

Our results demonstrate that, in sweetpotato, embryogenic callus and embryo production per unit mass of cultured callus is greater from 180 - to $250-\mu \mathrm{m}$ aggregates than from larger aggregates. The $180-$ to $250-\mu \mathrm{m}$ fraction also produced individualized embryos. However, sweetpotato somatic embryos initiated on large cell aggregates develop to the torpedo- and cotyledonary-stage aggregates while they remain arrested at the globular stage on small cell aggregates (Chée and Cantliffe, 1988a, 1989a, 1989b). In sweetpotato, only torpedo- and cotyledonary-stage embryos produce plants (Chée and Cantliffe, 1988b). Consequently, we are using in our current synthetic seed system the larger (500 to $1000 \mu \mathrm{m}$ ) aggregates for embryo production and the smaller cell aggregates for callus production until media and incubation conditions are defined for embryo development to a more advanced stage on small aggregates.

Our present findings are significant to programs for synthetic seed systems through somatic embryogenesis because they demonstrate the importance of cell aggregate size in producing high yields of embryogenic callus and embryos. Further, our data underline the importance of continued research for defining culture conditions and protocols for homogeneous liquid culture of cell aggregates of desirable sizes.

\section{Literature Cited}

Chée, R.P. and D.J. Cantliffe. 1988a. Selective enhancement of Ipomoea batatas Poir. embryogenic and non-embryogenic callus growth and production of embryos in liquid culture. Plant Cell Tissue Organ Cult. 15:149-159.

Chée, R.P. and D.J. Cantliffe. 1988b. Somatic embryony patterns and plant regeneration in lpomoea batatas Poir. In Vitro Cell Der Biol. 24:955-958.

Chée, R.P. and D.J. Cantliffe. 1989a. Composition of embryogenic liquid cultures of lpomoea batatas Poir. and production of individualized embryos from cell aggregate suspensions. Plant Cell Tissue Organ Cult. 17:39-52.

Chée, R.P. and D.J. Cantliffe. 1989b. Embryo development from discrete cell aggregates in Ipomoea batatas (L.) Lam. in response to structural polarity. In Vitro Cell Der Biol. 2.5:757760.

Chée, R.P., D.I. Leskovar, and D.J. Cantliffe. 1992. Optimizing embryogenic callus and embryo growth of a synthetic seed system for sweetpotato by varying nutrient concentrations of the culture media. J. Amer. Soc. Hort. Sci. 117:663-667.

Fujimura, T. and A. Komamine. 1979. Synchronization of somatic embryogenesis in carrot cell suspension culture. Plant Physiol. 64:162-164.

Halperin, W. 1964. Morphogenetic studies with partially synchonized cultures of carrot em- bryos. Science 146:408-410.

Halperin, W. 1966. Alternative morphogenetic events in cell suspensions. Amer. J. Bot. 53:443453.

Halperin, W. 1967. Population density effects on embryogenesis in carrot cell cultures. Expt. Cell Res. 48:170-173.

Halperin, W. and W.A. Jensen. 1967. Ultrastructural changes during growth and embryogenesis in carrot cell cultures. J. Ultrastructure Res. 18:428-443.

Halperin, W. and D.F. Wetherell. 1964. Ontogeny of adventive embryos of wild carrot. Science 147:756-758.

Halperin, W. and D.F. Wetherell. 1965. Ammonium requirement for embryogenesis in vitro. Nature (London) 205:519-520.

Jones, L.H. 1974. Factors influencing embryogenesis in carrot cultures (Daucus carota L.). Ann. Bot. 38:1077-1088.

Liu, J.R. and D.J. Cantliffe. 1984. Somatic embryogenesis and plant regeneration in time culture of sweet potato (Ipomoea batatas Poir.) Plant Cell Rptr. 3:112-115.

McWilliam, A.A., S.M. Smith, and H.E. Street. 1974. The origin and development of embryoids in suspension cultures of carrot (Daucus carota L.). Ann. Bot. 38:243-250.

Murashige, T. and F. Skoog. 1962. A revised medium for rapid growth and bioassays with tobacco tissue culture. Physiol. Plant. 15:473497. 